\title{
Differential Production of Phytotoxins from Phomopsis sp. from Grapevine Plants Showing Esca Symptoms
}

\author{
Mary-Lorène Goddard, ${ }^{\dagger, \dagger}$ Nicolas Mottier, ${ }^{\dagger, \perp}$ Julie Jeanneret-Gris, ${ }^{\dagger}$ Danilo Christen, ${ }^{\S, \#}$ Raphaël Tabacchi, ${ }^{\dagger}$ \\ and Eliane Abou-Mansour*, ${ }^{\dagger}, \|$ \\ ${ }^{\dagger}$ Institute of Chemistry, University of Neuchâtel, Rue Emile Argand 11, CH-2009 Neuchâtel, Switzerland \\ ${ }^{\ddagger}$ Laboratoire de Chimie Organique et Bioorganique, Université de Haute-Alsace-ENSCMu, 3 bis rue A. Werner, 68093 Mulhouse \\ cedex, France \\ ${ }^{\S}$ Phytopathology Group, Institute of Integrative Biology, Swiss Federal Institute of Technology, CH-8092 Zürich, Switzerland \\ "Plant Biology, Department of Biology, University of Fribourg, Chemin du Musée 10, 1700 Fribourg, Switzerland

\section{Supporting Information}

\begin{abstract}
Nine strains of the fungus Phomopsis spp. were isolated from a vineyard showing decline from the disease esca. Strains were screened for their ability to produce secondary metabolites showing chemical diversity. The culture extracts of each strain were analyzed by liquid chromatography-ultraviolet-diode array detection-mass spectrometry. Three strains were selected for the isolation and characterization of eight of the major metabolites. Structures were elucidated by spectroscopic analyses including two-dimensional NMR and mass spectrometry and by comparison to literature data. Among the isolated metabolites were the known phomopsolide B (1), sydowinin A (6), sydowinol (7), cytosporone B (8), and four new furanones named phomopsolidones A-D (2-5). The fungal strains were identified as Phomopsis sp., Phomopsis viticola Sacc and, Phomopsis viticola complex. Biological assays on Vitis vinifera leaves and callus tissue, antibacterial, and insecticidal activities were evaluated. The results revealed variability regarding secondary metabolites with species of Phomopsis sp. associated with grapevine, raising the question of cultivar-driven strain selection and phytotoxins biosynthesis in grapevine plants.
\end{abstract}

KEYWORDS: Phomopsis sp., Phomopsis viticola, phytotoxins, grapevine, esca

\section{INTRODUCTION}

Esca, one of the grapevines trunk disease, causes decline and premature dieback of vineyards and has become a growing threat to grapevines worldwide. ${ }^{1}$ The disease is most damaging when wet weather occurs early in the season. The disease does not spread rapidly but builds up progressively in a vineyard over a number of years, leading to a general decline in vigor and yield of the vines. ${ }^{2}$ The foliar symptoms are characterized by interveinal chlorosis that later develops into large necrotic areas in summer. ${ }^{2}$ More than a 158 fungal species have been reported from the necrotic wood of adult plants showing esca symptoms, ${ }^{3-5}$ mainly Phaeomoniella chlamydospora, Phaeoacremonium aleophilum, Fomitiporia mediterranea, Eutypa lata, Cadophora sp., Botryosphaeria sp., and Phomopsis sp. fungal species have been reported to have medium to high incidence. Phomopsis viticola is a fungus responsible for the phomopsis cane blight and leaf spot disease ${ }^{6}$ of grapevine and is more often reported together with the Botryosphaeriacea from esca symptomatic plants. ${ }^{5}$ In grapevine trunk disease, pathogens are isolated from both symptomatic and asymptomatic plants, and it remains unclear whether fungi act successively and/or in combination and whether wood-inhabiting microflora influences the decay process. ${ }^{5}$ The endophytic genus Phomopsis sp. comprises plant pathogens often associated with disease of agricultural crops and is known to be a rich source of bioactive secondary metabolites with diverse structures, ${ }^{7}$ but to our knowledge, there have been no reports of secondary metabolites isolated from the grapevine pathogen $P$. viticola
Sacc. Since the fungus cannot be detected in leaves of infected grapevine trunk diseased plants, it was hypothesized that foliar symptoms are caused by toxic compounds produced by the fungi in wood tissue that are either translocated to the leaves or induce chain reactions leading to the symptoms on the leaves. A comprehensive review highlighting the metabolites biosynthesized by some of the fungi inhabiting the wood of grapevine has been published. ${ }^{8}$

In an ongoing effort to identify phytotoxic metabolites from pathogenic fungi of grapevine trunk disease, ${ }^{9-11}$ we investigated several strains of Phomopsis isolated from V. vinifera Merlot, Cabernet sauvignon, and Cabernet franc showing or not esca symptoms. We report here the isolation and structural elucidation of eight metabolites isolated from three different strains of Phomopsis sp. Their phytotoxicity was assessed on grapevine leaves and callus tissue as well as their antimicrobial and larvicidal activities. Finally, a correlation between cultivars susceptibility, strain species, and their capacity to biosynthesize secondary metabolites was attempted.

\section{MATERIALS AND METHODS}

General Experimental Procedures. ${ }^{1} \mathrm{H}$ and ${ }^{13} \mathrm{C}$ NMR spectra were recorded on a Bruker AMX 400 spectrometer (400 MHz) 
Table 1. ${ }^{1} \mathrm{H}$ and ${ }^{13} \mathrm{C}$ NMR (400 and $100 \mathrm{MHz}$ ) Spectral Data of Compounds $2-5\left(\mathrm{CDCl}_{3}, \delta\right.$ in ppm, $J$ in hertz)

\begin{tabular}{|c|c|c|c|c|c|c|}
\hline & \multicolumn{3}{|c|}{ compd 2} & \multicolumn{3}{|c|}{ compd 3} \\
\hline & $\delta \mathrm{C}$ & $\delta \mathrm{H}$ & $\mathrm{HMBC}\left({ }^{1} \mathrm{H}-{ }^{13} \mathrm{C}\right)$ & $\delta \mathrm{C}$ & $\delta \mathrm{H}$ & HMBC $\left({ }^{1} \mathrm{H}-{ }^{13} \mathrm{C}\right)$ \\
\hline 2 & 172.4 & & & 176.9 & & \\
\hline 3 & 123.3 & $6.21(\mathrm{dd}, 2.0,5.8)$ & $\mathrm{C} 2-\mathrm{C} 5$ & 28.1 & $2.56(\mathrm{~m})$ & $\mathrm{C} 5$ \\
\hline 4 & 152.6 & $7.45(\mathrm{dd}, 1.6,5.8)$ & $\mathrm{C} 2-\mathrm{C} 5$ & 23.7 & $\begin{array}{l}2.34 \text { (dddd, } 7.7,7.7,9.2,13.2 \text { ) } \\
2.08 \text { (dddd, } 5.5,7.7,9.2,13.2)\end{array}$ & $\begin{array}{l}\mathrm{C} 6 \\
\mathrm{C} 5\end{array}$ \\
\hline 5 & 83.3 & $5.21(\mathrm{ddd}, 1.6,2.0,4.1)$ & $\mathrm{C} 4-\mathrm{C} 6-\mathrm{C}^{\prime}$ & 80.1 & $4.69(\mathrm{ddd}, 4.4,5.5,7.7)$ & $\mathrm{C} 3-\mathrm{C} 4-\mathrm{C} 6$ \\
\hline 6 & 71.7 & $5.64(\mathrm{dd}, 4.1,6.0)$ & $\mathrm{C} 4-\mathrm{C} 5-\mathrm{C}^{\prime}-\mathrm{C} 2^{\prime}$ & 74.6 & $5.47(\mathrm{dd}, 4.4,5.5)$ & $\mathrm{C} 5-\mathrm{C} 2^{\prime}-\mathrm{C} 1^{\prime \prime}$ \\
\hline $1^{\prime}$ & 125.7 & $5.85(\mathrm{dd}, 6.0,15.6)$ & $\mathrm{C} 6-\mathrm{C}^{\prime}$ & 126.2 & $5.88(\mathrm{ddd}, 1.0,6.0,15.5)$ & $\mathrm{C} 6-\mathrm{C}^{\prime}{ }^{\prime}-\mathrm{C} 2^{\prime}-\mathrm{C} 3^{\prime}$ \\
\hline $2^{\prime}$ & 135.5 & $5.92(\mathrm{dd}, 5.4,15.6)$ & $\mathrm{C} 6-\mathrm{Cl}^{\prime}$ & 135.2 & $5.88(\mathrm{ddd}, 1.0,6.0,15.5)$ & $\mathrm{C} 1^{\prime}$ \\
\hline $3^{\prime}$ & 76.2 & $3.93(\mathrm{dd}, 5.4,6.3)$ & $\mathrm{C} 1^{\prime}-\mathrm{C} 2^{\prime}-\mathrm{C}^{\prime}-\mathrm{C}^{\prime}$ & 76.3 & $3.93(\mathrm{dd}, 4.6,6.3)$ & $\mathrm{C} 1^{\prime}-\mathrm{C} 2^{\prime}-\mathrm{C} 4^{\prime}-\mathrm{C} 5^{\prime}$ \\
\hline $4^{\prime}$ & 70.5 & $3.68(\mathrm{qt}, 6.3)$ & $\mathrm{C} 2^{\prime}-\mathrm{C} 3^{\prime}-\mathrm{C} 5^{\prime}$ & 70.4 & $3.68(\mathrm{qt}, 6.3)$ & $\mathrm{C} 2^{\prime}-\mathrm{C} 3^{\prime}-\mathrm{C} 5^{\prime}$ \\
\hline $5^{\prime}$ & 18.8 & $1.20(\mathrm{~d}, 6.3)$ & $\mathrm{C} 3^{\prime}$ & 18.9 & $1.20(\mathrm{~d}, 6.3)$ & \\
\hline $1^{\prime \prime}$ & 166.5 & & & 166.8 & & \\
\hline $2^{\prime \prime}$ & 127.7 & & & 128.0 & & \\
\hline $2^{\prime \prime}-\mathrm{Me}$ & 14.5 & $1.83(\mathrm{~d}, 1.7)$ & $\mathrm{C} 1^{\prime \prime}-\mathrm{C} 2^{\prime \prime}-\mathrm{C} 4^{\prime \prime}$ & 14.6 & $1.86(\mathrm{~d}, 1.2)$ & $\mathrm{C} 3^{\prime \prime}$ \\
\hline $3^{\prime \prime}$ & 139.2 & $6.90(\mathrm{qq}, 1.7,7.3)$ & $\mathrm{C} 1^{\prime \prime}-\mathrm{C} 4^{\prime \prime}$ & 139.1 & $6.92(\mathrm{qq}, 1.2,7.0)$ & $\mathrm{C} 1^{\prime \prime}$ \\
\hline $4^{\prime \prime}$ & 11.9 & $1.82(\mathrm{~d}, 7.3)$ & $\mathrm{C} 3^{\prime \prime}-\mathrm{C} 2^{\prime \prime}-\mathrm{C} 2^{\prime \prime}-\mathrm{Me}$ & 12.1 & $1.83(\mathrm{~d}, 7.0)$ & $\mathrm{C} 3{ }^{\prime \prime}$ \\
\hline $3^{\prime}-\mathrm{OH}$ & & 1.91 (br s) & & & 1.28 (br s) & \\
\hline $4^{\prime}-\mathrm{OH}$ & & 1.91 (br s) & & & 1.28 (br s) & \\
\hline
\end{tabular}

(Fällenden, Switzerland). Chemical shifts were referenced to TMS. Optical rotations were determined on a PerkinElmer 241 digital polarimeter (Waltham, MA, USA) with a $1 \mathrm{dm}$ cell. IR spectra were obtained on a PerkinElmer $1720 \mathrm{X}$ spectrometer. UV spectra were recorded on a Shimadzu UV-190. High-performance liquid chromatography (HPLC) analysis and purification was carried out on an Agilent 1100 (Palo Alto, CA, USA) coupled to a diode array detector (DAD). Mass spectra were measured on an Agilent 1100 LCMSD Trap using the electrospray ionization (ESI) source in negative or positive ionization mode. High-resolution electrospray ionization mass spectrometry (HRESI MS) was performed on a Bruker FTMS 4.7T BioAPEX II or an Agilent 3100 QTof.

Plant Materials and Fungal Strain Isolation. Ten plants of 15 years old of $V$. vinifera cv. Merlot, Cabernet sauvignon, and Cabernet franc were rooted in 2003 for further analysis from a vineyard in Riva San Vitale (Ticino, Switzerland). Half of the plants already exhibited esca foliar symptoms in 2000 and/or 2001. Plants were ripped out and cut in disks as reported. ${ }^{12}$

Strain Growth and Extraction Method for Strain Screening. Nine strains of Phomopsis sp. (DC110, DC275, DC283, DC180, DC239, DC279, DC281, DC282, and DC301,) were isolated and maintained on potato dextrose agar (PDA) (Difco, Sparks, MD, USA) (Table 2) for chemical analysis. For each strain, 10 replicates were grown from 7 day old native cultures and incubated at $25{ }^{\circ} \mathrm{C}$ in the dark. The fungal cultures were extracted separately with ethyl acetate $(\mathrm{EtOAc})(3 \times 600 \mathrm{~mL})$ and evaporated under reduced pressure to dryness. An aliquot $(10 \mathrm{mg} / \mathrm{mL})$ was dissolved in $\mathrm{MeOH}$ for LCDAD-MS analysis, and $20 \mu \mathrm{L}$ was examined by reverse-phase chromatography (Nucleosil 100-7, C-18, $250 \mu \mathrm{m} \times 4.6 \mu \mathrm{m}, 7 \mu \mathrm{m}$, Machery-Nagel, Duren, Germany) on a gradient of methanol and water starting at $40 \%$ of methanol for $5 \mathrm{~min}$, increasing to $90 \%$ at 30 min and to $100 \%$ at $40 \mathrm{~min}$ at the flow rate of $1 \mathrm{~mL} / \mathrm{min}$.

Growth Conditions and Extraction Methods. Four strains were selected for their chemical diversity and identified by the Belgium Coordinated Collections of Microorganisms (BCCM) as Phomopsis sp. DC275 isolated from asymptomatic cv. Merlot, P. viticola complex DC239 isolated from asymptomatic cv. Cabernet sauvignon and DC281 isolated from symptomatic Cabernet franc, and finally, $P$. viticola (Sacc.) Sacc. DC180 isolated from asymptomatic cv. Cabernet Sauvignon. Three strains (DC275, DC239, and DC180) were selected for high scale culture. Each strain was grown on 40 PDA Petri plates for 21 days at $25{ }^{\circ} \mathrm{C}$ in the dark. Cultures were extracted with EtOAc $(3 \times 3 \mathrm{~L})$ to yield dry residues of $1.68 \mathrm{~g}$ for DC275, $1.8 \mathrm{~g}$ for DC239, and $1.0 \mathrm{~g}$ for DC180. Crude extract of each strain was dissolved in water and extracted with $n$-hexane for defatting.

The remaining defatted material from Phomopsis sp. DC275 was further extracted with dichloromethane $\left(\mathrm{CH}_{2} \mathrm{Cl}_{2}\right)$. This extract showed the highest phytotoxic activity against grape leaves and was further purified by a successive column chromatography (CC) on $\mathrm{Si}$ gel $60^{\circ} \mathrm{A}$ eluted with a gradient solvent of $n$-hexane $/ \mathrm{CH}_{2} \mathrm{Cl}_{2}(1: 1, \mathrm{v} / \mathrm{v})$ to $\mathrm{CH}_{2} \mathrm{Cl}_{2} / \mathrm{MeOH}(1: 1, \mathrm{v} / \mathrm{v})$. A final purification by the solvent mixture $\mathrm{CHCl}_{3} / i \mathrm{PrOH}(9: 1, \mathrm{v} / \mathrm{v})$ afforded three pure compounds 1 $(75 \mathrm{mg}), 2(3.2 \mathrm{mg})$, and $\mathbf{3}(3.6 \mathrm{mg})$ and a mixture of $\mathbf{4}$ and $\mathbf{5}$ (10 $\mathrm{mg})$.

Ethyl acetate extracts from $P$. viticola complex DC239 and P. viticola Sacc. DC180 were subjected to Sephadex LH-20 $(70 \mathrm{~cm} \times 1.2 \mathrm{~cm})$ CC (GE Healthcare, Piscataway, NJ, USA). The eluent was a mixture of chloroform/methanol $(1: 1, \mathrm{v} / \mathrm{v})$ for the first extract and methanol for the second one. The final pure compounds from the strain DC239 were obtained by purification with semipreparative HPLC using a gradient of $\mathrm{MeOH} / \mathrm{H}_{2} \mathrm{O}$ (starting with $70 \% \mathrm{MeOH}$ and reaching $80 \%$ $\mathrm{MeOH}$ after $15 \mathrm{~min}$, at the flow rate of $3.5 \mathrm{~mL} / \mathrm{min}$ on a Nucleosil 100-7 C-18 column, $(250 \mathrm{~mm} \times 8 \mathrm{~mm}$ i.d., Macherey-Nagel, Düren, Germany). P. viticola complex afforded three compounds 6 (7 mg), 7 $(1.3 \mathrm{mg})$, and $8(2 \mathrm{mg})$. Finally, using the same HPLC conditions as above, the strain (DC181) afforded 8 ( $8 \mathrm{mg})$.

Phomopsolide $B$ (1). Colorless needles $(75 \mathrm{mg}) ;[\alpha]_{\mathrm{D}}^{25}+183.1^{\circ}$ (MeOH; $c$ 0.47); HRESI MS (+) $m / z 319.1153[\mathrm{M}+\mathrm{Na}]^{+}$(calcd for $\left.\mathrm{C}_{15} \mathrm{H}_{20} \mathrm{O}_{6} \mathrm{Na} 319.1152\right) ; \mathrm{IR}$ ( $\mathrm{KBr}$ disc) $\nu_{\max } \mathrm{cm}^{-1}: 3562,3394,2915$, $1710,1649,1456,1380,1259,1135,1065,976,826,733$; UV $(\mathrm{MeOH}) \lambda_{\max } \mathrm{nm}(\log \varepsilon): 227$ (4.36); ${ }^{1} \mathrm{H}$ NMR $\left(\mathrm{CDCl}_{3}\right) \delta_{\mathrm{H}} 1.15$ $\left(\mathrm{CH}_{3}, \mathrm{~d}, 6.3 \mathrm{~Hz}\right), 1.79\left(\mathrm{CH}_{3}, \mathrm{~d}, 7.3 \mathrm{~Hz}\right), 1.81(\mathrm{CH}, \mathrm{d}, 1.8 \mathrm{~Hz}), 2.83$ (OH, br s), $2.83(\mathrm{OH}, \mathrm{br} \mathrm{s}), 3.60(\mathrm{CHOH}, \mathrm{qt}, 6.3 \mathrm{~Hz}), 3.91(\mathrm{CHOH}$, t, $6.0 \mathrm{~Hz}), 5.11(\mathrm{CH}, \mathrm{dd}, 3.0,5.9 \mathrm{~Hz}), 5.37(\mathrm{CH}, \mathrm{dd}, 3.0,5.5 \mathrm{~Hz}), 5.88$ (CH, ddd, 1.0, 5.9, $15.7 \mathrm{~Hz}), 6.00(\mathrm{CH}$, ddd, 1.0, 6.0, $15.7 \mathrm{~Hz}), 6.22$ $(\mathrm{CH}, \mathrm{d}, 9.7 \mathrm{~Hz}), 7.01(\mathrm{CH}, \mathrm{dd}, 5.5,9.7 \mathrm{~Hz}) ;{ }^{13} \mathrm{C} \mathrm{NMR} \delta_{\mathrm{C}} 11.9\left(\mathrm{CH}_{3}\right)$, $14.4\left(\mathrm{CH}_{3}\right), 18.6\left(\mathrm{CH}_{3}\right), 63.3(\mathrm{CH}), 70.4(\mathrm{CH}), 76.0(\mathrm{CH}), 78.6$ $(\mathrm{CH}), 124.4(\mathrm{CH}), 124.7(\mathrm{CH}), 124.4(\mathrm{CH}), 127.4(\mathrm{C}), 135.0(\mathrm{C})$, $139.8(\mathrm{CH}), 141.0(\mathrm{CH}), 162.5(\mathrm{CO}), 166.7(\mathrm{CO})$.

Phomopsolidone A (2). Colorless oil $(3.2 \mathrm{mg}) ;[\alpha]{ }_{\mathrm{D}}^{25}-19.7^{\circ}$ $\left(\mathrm{MeOH} ; \mathrm{c}\right.$ 0.32); HRESI MS $(+) \mathrm{m} / z 319.1153[\mathrm{M}+\mathrm{Na}]^{+}$(calcd for $\mathrm{C}_{15} \mathrm{H}_{20} \mathrm{O}_{6} \mathrm{Na} 319.1152$ ); IR (film) $\nu_{\max } \mathrm{cm}^{-1}: 3435,2917,1749,1648$, $1455,1385,1261,1130,1077,980,822,734 ; \mathrm{UV}(\mathrm{MeOH}) \lambda_{\max } \mathrm{nm}$ $(\log \varepsilon): 233$ (4.41); for ${ }^{1} \mathrm{H}$ and ${ }^{13} \mathrm{C}$ NMR data see Table 1.

Phomopsolidone B (3). Colorless oil (2.6 mg); $[\alpha]{ }_{\mathrm{D}}^{25}-15.1^{\circ}$ $\left(\mathrm{MeOH} ; c\right.$ 0.26); HRESI MS (1) $\mathrm{m} / z 321.1309[\mathrm{M}+\mathrm{Na}]^{+}$(calcd for $\mathrm{C}_{15} \mathrm{H}_{22} \mathrm{O}_{6} \mathrm{Na}$ 321.1308); IR (film) $\nu_{\max } \mathrm{cm}^{-1}: 3419,2926,1767,1707$, 
$1649,1564,1440,1382,1264,1138,1078,979,735$; UV $(\mathrm{MeOH})$ $\lambda_{\max }$ nm $\left(\log \varepsilon\right.$ ): 237 (4.38); for ${ }^{1} \mathrm{H}$ and ${ }^{13} \mathrm{C}$ NMR data see Table 1. Phomopsolidone C (4) and D (5). Colorless oil (10 mg); HRESI MS (+) $m / z 219.0637[\mathrm{M}+\mathrm{Na}]^{+}$(calcd for $\mathrm{C}_{10} \mathrm{H}_{12} \mathrm{O}_{4} \mathrm{Na}, 219.0627$ ); $\mathrm{UV}(\mathrm{MeOH}) \lambda_{\max } \mathrm{nm}(\log \varepsilon): 227$ (3.72). Phomopsolidone $C(4){ }^{1} \mathrm{H}$ $\operatorname{NMR}\left(\mathrm{CDCl}_{3}\right) \delta_{\mathrm{H}} 1.22\left(\mathrm{CH}_{3}, \mathrm{~d}, 6.6 \mathrm{~Hz}\right), 3.71(\mathrm{CH}, \mathrm{qt}, 6.6 \mathrm{~Hz}), 4.03$ $(\mathrm{CH}$, tapp, $6.6 \mathrm{~Hz}), 5.86(\mathrm{CH}, \mathrm{d}, 11.2 \mathrm{~Hz}), 6.05(\mathrm{CH}, \mathrm{dd}, 6.6,15.5$ $\mathrm{Hz}), 6.21$ (CH, d, 5.4), $6.86(\mathrm{CH}, \mathrm{ddd}, 1.2,11.2,15.5 \mathrm{~Hz}), 7.41(\mathrm{CH}$, d, $5.4 \mathrm{~Hz}) ;{ }^{13} \mathrm{C}$ NMR $\left(\mathrm{CDCl}_{3}\right) 19.1\left(\mathrm{CH}_{3}\right), 70.6(\mathrm{CH}), 77.2(\mathrm{CH})$, $113.2(\mathrm{CH}), 119.5(\mathrm{CH}), 125.0(\mathrm{CH}), 139.1(\mathrm{CH}), 143.3(\mathrm{CH})$ 149.1 (C), 169.5 (CO). Phomopsolidone D (5) ${ }^{1} \mathrm{H} \mathrm{NMR}\left(\mathrm{CDCl}_{3}\right) \delta_{\mathrm{H}}$ $1.22\left(\mathrm{CH}_{3}, \mathrm{~d}, 6.6 \mathrm{~Hz}\right), 3.71(\mathrm{CH}, \mathrm{qt}, 6.6 \mathrm{~Hz}), 4.03(\mathrm{CH}$, tapp, $6.6 \mathrm{~Hz})$, $5.86(\mathrm{CH}, \mathrm{d}, 11.2 \mathrm{~Hz}), 6.05(\mathrm{CH}, \mathrm{dd}, 6.6,15.5 \mathrm{~Hz}), 6.21(\mathrm{CH}, \mathrm{d}, 5.4)$, $6.86(\mathrm{CH}, \mathrm{ddd}, 1.2,11.2,15.5 \mathrm{~Hz}), 7.41(\mathrm{CH}, \mathrm{d}, 5.4 \mathrm{~Hz}) ;{ }^{13} \mathrm{C} \mathrm{NMR}$ $\left(\mathrm{CDCl}_{3}\right) 19.2\left(\mathrm{CH}_{3}\right), 70.8(\mathrm{CH}), 77.3(\mathrm{CH}), 114.5(\mathrm{CH}), 120.2$ (CH), $124.1(\mathrm{CH}), 139.3(\mathrm{CH}), 143.2(\mathrm{CH}), 150.9(\mathrm{C}), 169.4(\mathrm{CO})$. Sydowinin A (6). Yellowish powder (7 mg). ESI MS (+) $m / z 323.1$ $[\mathrm{M}+\mathrm{Na}]^{+}$calcd for $\mathrm{C}_{16} \mathrm{O}_{6} \mathrm{H}_{12} \mathrm{Na}$; IR (film) $\nu_{\max } \mathrm{cm}^{-1}: 3430,1735$, 1720, 1649, 1620, 1600; UV (MeOH) $\lambda_{\max } \mathrm{nm}(\log \varepsilon): 233$ (3.81), 257 (3.78), 291 (2.7), 362 (1.9). ${ }^{1} \mathrm{H} \mathrm{NMR}\left(\mathrm{CDCl}_{3}\right) \delta_{\mathrm{H}} 4.0\left(\mathrm{CH}_{3}, \mathrm{~s}\right)$, $4.75\left(\mathrm{CH}_{2}, \mathrm{~s}\right), 6.70(\mathrm{CH}, \mathrm{d}, 1.3 \mathrm{~Hz}), 6.95(\mathrm{CH}, \mathrm{d}, 1.3 \mathrm{~Hz}), 7.33(\mathrm{CH}$, dd, $6.9 ; 2.6 \mathrm{~Hz}), 7.56(\mathrm{CH}, \mathrm{dd}, 6.9 ; 2.9 \mathrm{~Hz}), 7.78(\mathrm{CH}, \mathrm{dd}, 6.9 \mathrm{~Hz})$, 12.1(OH, s); ${ }^{13} \mathrm{C} \mathrm{NMR}\left(\mathrm{CDCl}_{3}\right) \delta_{\mathrm{C}} 133.8(\mathrm{C}), 122.9(\mathrm{CH}), 135.4$ $(\mathrm{CH}), 119.9(\mathrm{CH}), 156.4(\mathrm{C}), 156.3(\mathrm{C}), 104.5(\mathrm{CH}), 152.5(\mathrm{C})$, 108.5 (CH), 162.0 (C), 108.2 (C), 117.8 (C), 180.9 (C), 170.0 (C), $53.6\left(\mathrm{CH}_{3}\right), 64.7\left(\mathrm{CH}_{2}\right)$.

Sydowinol (7). Yellow powder (1.3 mg), HRESI MS (-) $\mathrm{m} / \mathrm{z}$ $315.0532[\mathrm{M}-\mathrm{H}]^{-}$(calcd for $\mathrm{C}_{16} \mathrm{O}_{7} \mathrm{H}_{12}, 315.0510$ ); IR (film) $\nu_{\max }$ $\mathrm{cm}^{-1}$ : 3430, 1728, 1720, 1656, 1585, 1550; UV (MeOH) $\lambda_{\max } \mathrm{nm}(\log$ $\varepsilon): 233$ (4.30), 257 (4.18), 291 (2.1), 362 (1.9); ${ }^{1} \mathrm{H}$ NMR $\left(\mathrm{MeOH}-d_{4}\right)$ $\delta_{\mathrm{H}} 3.96\left(\mathrm{CH}_{3}, \mathrm{~s}\right), 4.67\left(\mathrm{CH}_{2}, \mathrm{~s}\right), 6.73(\mathrm{CH}, \mathrm{d}, J=1.1 \mathrm{~Hz}), 6.97(\mathrm{~d}, J=$ $1.1 \mathrm{~Hz}), 7.37(\mathrm{~d}, J=9.1 \mathrm{~Hz}), 7.51(\mathrm{~d}, J=9.1 \mathrm{~Hz}) ;{ }^{13} \mathrm{C} \mathrm{NMR}(\mathrm{MeOH}-$ $\left.d_{4}\right), \delta_{\mathrm{C}} 52.23\left(\mathrm{CH}_{3}\right), 63.36\left(\mathrm{CH}_{2}\right), 104.25(\mathrm{CH}), 107.49(\mathrm{C}), 120.30$ (C), 118.06 (C), 125.05 (CH), 130.39 (C), 150.02 (C), 151.37 (C), 153.3 (C), 156.5 (C), 161.65 (C), 169.2 (C), 181.12 (C).

Cytosporone $B(8)$. Colorless powder (9 mg); HRESI MS $(+)[\mathrm{M}+$ $\mathrm{Na}]^{+} m / z 345.1674$ (calcd for $\mathrm{C}_{18} \mathrm{H}_{27} \mathrm{O}_{5} \mathrm{Na}, 345.1672$ ). ESI MS ${ }^{2}(-$ ) of $m / z 321.3[\mathrm{M}-\mathrm{H}]^{-}$gave the fragment $275\left[\mathrm{M}-\mathrm{C}_{2} \mathrm{H}_{5} \mathrm{OH}-\mathrm{H}\right]^{-}$; IR (film) $\nu_{\max } \mathrm{cm}^{-1}: 3234,1732,1622,1456,1368,1174 \mathrm{~cm}^{-1}$; UV $\left(\mathrm{CH}_{3} \mathrm{CN}\right) \lambda_{\max } \mathrm{nm}(\log \varepsilon): 219(4.33), 268(3.33) ;{ }^{1} \mathrm{H}$ NMR $\left(\mathrm{CDCl}_{3}\right)$ $\delta_{\mathrm{H}} 6.30(\mathrm{CH}, \mathrm{d}, 2.4 \mathrm{~Hz}), 6.28(\mathrm{CH}, \mathrm{d}, 2.4 \mathrm{~Hz}), 4.22(2 \mathrm{H}, \mathrm{t}, 7 \mathrm{~Hz}), 3.85$ (2H, s), $2.84(2 \mathrm{H}, \mathrm{t}, 7), 1.26-1.27-1.28-1.29-1.32(8 \mathrm{H}, \mathrm{bm}) 1.30$ $(3 \mathrm{H}, \mathrm{t}, 7 \mathrm{~Hz}), 0.88(3 \mathrm{H}, \mathrm{t}, 7 \mathrm{~Hz}) ;{ }^{13} \mathrm{C} \mathrm{NMR}\left(\mathrm{CDCl}_{3}\right) \delta_{\mathrm{C}} 171.9(\mathrm{C})$, $42.2\left(\mathrm{CH}_{2}\right), 137.0(\mathrm{C}), 103.7(\mathrm{CH}), 160.8(\mathrm{C}), 113.1(\mathrm{CH}), 160.8$ (C), $207.1(\mathrm{C}), 117.0(\mathrm{C}), 43.8\left(\mathrm{CH}_{2}\right), 25.4\left(\mathrm{CH}_{2}\right), 29.5\left(\mathrm{CH}_{2}\right), 29.6$ $\left(\mathrm{CH}_{2}\right), 32.1\left(\mathrm{CH}_{2}\right), 23.0\left(\mathrm{CH}_{3}\right), 14.5\left(\mathrm{CH}_{3}\right), 62.1\left(\mathrm{CH}_{2}\right), 14.6\left(\mathrm{CH}_{3}\right)$.

Biological Assays. Grapevine Leaf Disc Assays. The compounds were dissolved in $2 \%$ aqueous ethanol at concentrations of 500, 250, and $100 \mu \mathrm{g} / \mathrm{mL}$. Grapevine leaves V. vinifera cv. Chasselas were cut into discs of $5 \mathrm{~mm}$ of diameter with a cork borer and immersed in 1 $\mathrm{mL}$ of the solutions. The phytotoxicity of the crude extracts and the pure compounds was evaluated by measuring the area of necrotic tissues related to the total leaf disc area. Eutypine was used as a positive control and $2 \%$ ethanol as a negative control.

Grapevine Callus Assay. Phomopsolide B (1) was also tested on grapevine callus tissue from Vitis vinifera cv. Gamay (kindly supplied by Prof. Roustan, INRA, Toulouse, France). Callus cultures were cultivated on a growth medium according to a method previously described ${ }^{11}$ with $12 \mathrm{~h}$ daylight for 28 days at $28^{\circ} \mathrm{C}$. Calli were weighed before and after incubation, and percent growth was calculated.

Antibacterial Assays. The antibacterial activity was measured by the bioautography method on thin-layer chromatography plates. Different concentrations of test compounds were prepared by the 2fold serial dilution method described previously. ${ }^{13}$

Larvicidal Efficiency. Phomopsolide B (1) and phomopsolidones A (2) and B (3) were screened for larvicidal activities. The assay was performed at the Research Station Agroscope Changins-Wädenswil (Nyon, Switzerland) according to a method previously described. ${ }^{14}$ In short, Lobesia botrana larvae were reared on an artificial diet of "Manduca - Heliothis Premix" (Stonefly Industries, Bryan, TX, USA) containing the dissolved product. By using a spatula, 1-2 $\mathrm{g}$ of the contaminated diet ( 1 and $10 \mathrm{ppm}$ ) was placed into each of 60 small plastic boxes. One newborn larva from rearing was then placed into each box. The larvae were reared under laboratory conditions at $25{ }^{\circ} \mathrm{C}$. After 14 days, a first count of the surviving larvae was made. Rearing was then continued to the adult stage. The development time of the larvae was also assessed.

\section{RESULTS AND DISCUSSION}

We investigated nine strains of Phomopsis isolated from grapevine plants showing esca symptoms in Ticino, Switzerland. Ten PDA Petri dishes of each strain were extracted with ethyl acetate and screened for secondary metabolites by HPLCDAD-MS analyses and for phytotoxic activity on grapevine leaf disc assays. Three strains DC275, DC239, and DC180 were selected for further study according to the chemical differences in the secondary metabolites produced.

The first strain Phomopsis sp. DC275, isolated from a Merlot cultivar, afforded five pure compounds, phomopsolide B (1) as the major compound and four new furanones (2-5) given the trivial names phomopsolidones A-D (Figure 1). The HRESI

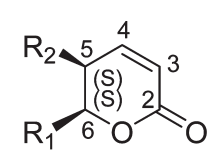

1<smiles>[R]COC(=O)/C(C)=C(/C)[CH]C</smiles><smiles>[R]COC(=O)/C(C)=C(/C)[CH]C</smiles><smiles>[R]C([R])[C@@]1([2H])C=CC(=O)O1</smiles>

2<smiles>[R]C([R2])[C@]1([2H])C[13CH]C(=O)O1</smiles>

3
Figure 1. Compounds isolated from Phomopsis sp. DC275: phomopsolide B (1) and phomopsolidones A-D (2-5).

MS (+) spectrum $m / z 319.1153[\mathrm{M}+\mathrm{Na}]^{+}$of $\mathbf{1}$ indicated a molecular formula of $\mathrm{C}_{15} \mathrm{H}_{20} \mathrm{O}_{6} \mathrm{Na}$ supported by detailed IR, $\mathrm{UV},{ }^{1} \mathrm{H},{ }^{13} \mathrm{C}$, one-dimensional (1D) and two-dimensional (2D) NMR, and MS data. The carbonyl group was also deduced from IR spectra and a signal at $\delta 162.5$ in the ${ }^{13} \mathrm{C}$ NMR spectrum. On the basis of COSY and HMBC and optical rotation spectra, compound $\mathbf{1}$ was identified as phomopsolide $\mathrm{B}$ (1) previously reported from cultures of Phomopsis species. ${ }^{15-17}$

Compound 2 showed the same molecular mass and HRESI MS (+) mass spectrum as $1 \mathrm{~m} / z 319.1153[\mathrm{M}+\mathrm{Na}]^{+}$with the same molecular formula $\mathrm{C}_{15} \mathrm{H}_{20} \mathrm{O}_{6} \mathrm{Na}$. The downfield shift of the carbonyl atom signal of C-2, C-4, C-5, and C-6 at $\delta 172.4, \delta$ 152.6, $\delta$ 83.3, and $\delta$ 71.7, respectively, in the ${ }^{13} \mathrm{C} \mathrm{NMR}$ spectrum indicated that the main differences occurred on the unsaturated $\gamma$-lactone moiety. Furthermore, the downfield chemical shift of H-3 $(\delta$ 6.21) and H-4 $(\delta$ 7.45) and the coupling constant $(J=1.6,2.0$, and 4.1$)$ between $\mathrm{H}-3, \mathrm{H}-4$, and $\mathrm{H}-5$ were characteristic of a 2 -furanone ring indicating that group 2-methyl-but-2-enoic acid substituted at C-5 of 1 migrated to C-6 of 2 inducing a shielding of the H-6 chemical shift $(\delta 5.64)$. Thus, compound 2 was isolated for the first time and named phomopsolidone A. 
Compound 3 named phomopsolidone $\mathrm{B}$ had a molecular mass of 298, HRESI MS (1) $m / z 321.1309[\mathrm{M}+\mathrm{Na}]^{+}$ indicating a molecular formula of $\mathrm{C}_{15} \mathrm{H}_{22} \mathrm{O}_{6} \mathrm{Na}$. The ${ }^{1} \mathrm{H}$ and ${ }^{13} \mathrm{C}$ NMR spectra of 3 , compared to those of 2 , indicated a hydrogenation of the furanone ring at positions C-3 and C-4 leading to a dihydrofuranone. However, the absolute configurations of $\mathbf{2}$ and $\mathbf{3}$ were not elucidated in this study, although the optical rotation spectra were similar to the results reported for the furanones from Nigrospora sacchari. ${ }^{18}$

Compounds 4 and 5, named phomopsolidones C and D, were obtained as a mixture of two isomers. Because of the low amount of compounds available and the lack of activity, no further purification was performed. Nevertheless, HRESI MS and ${ }^{1} \mathrm{H}$ and ${ }^{13} \mathrm{C}$ NMR spectra, compared to those of 2, indicated the presence of the furanone ring with the elimination of the group $\mathrm{R}_{2}$. The presence of two new carbon atoms at $\delta$ 149.1 and $\delta 113.5$ for compound 4 and $\delta 150.9$ and $\delta 114.5$ for compound 5 indicated the formation of an ethylenic bond between C-5 and C- 6 with the configuration $Z$ and E. A longrange coupling constant between $\mathrm{H}-3$ and $\mathrm{H}-4$ and $\mathrm{H}-6$ in compound 5, characteristic of a W system, indicated an $E$ configuration of the double bond between C-5 and C-6. HRESI MS (+) $m / z 219.0637[\mathrm{M}+\mathrm{Na}]^{+}$confirmed the molecular formula $\mathrm{C}_{10} \mathrm{H}_{12} \mathrm{O}_{4} \mathrm{Na}$.

The second strain DC239 afforded three compounds (Figure 2). Compound 6, a yellow amorphous solid, had a UV<smiles>COC(=O)C1=CC=CC2Oc3cc(CO)cc(O)c3C(=O)C12</smiles>

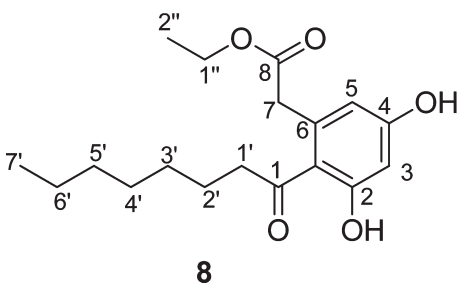

Figure 2. Compounds isolated from $P$. viticola complex and Sacc. DC239 and DC180: sydowinin A (6), sydowinol (7), and cytosporone B (8).

spectrum specific for a xanthone, with $\lambda_{\max }$ at $233,257,291$, $301,362 \mathrm{~nm}$. The molecular formula was deduced from ${ }^{1} \mathrm{H}$ NMR, ${ }^{13} \mathrm{C}$ NMR, DEPT, COSY, HMBC, and HMQC data as $\mathrm{C}_{16} \mathrm{O}_{6} \mathrm{H}_{12}$ according to ESI MS $(+) m / z 300.09[\mathrm{M}+\mathrm{H}]^{+}$and $\mathrm{MS}^{2} \mathrm{~m} / z 269.2$ corresponded to the loss of a methoxyl group. Thus, compound 6 was identified as sydowinin A previously described from Aspergillus sydowii. ${ }^{19}$

The molecular formula $\mathrm{C}_{16} \mathrm{O}_{7} \mathrm{H}_{12}$ for 7 was deduced from ${ }^{1} \mathrm{H}$ NMR, ${ }^{13} \mathrm{C}$ NMR, and DEPT data combined with MS data. The HRESI MS (-) $m / z 315.0532[\mathrm{M}-\mathrm{H}]^{-}$and $\mathrm{MS}^{2} m / z 285.2$ corresponded to the loss of the group methoxyl. 2D NMR data allowed the identification of compound 7 as sydowinol. ${ }^{19}$ However, the identification of compounds 6 and 7 was reported only by ${ }^{1} \mathrm{H}$ NMR data; we report, in the Materials and Methods section, the complete spectral characterization by ${ }^{13} \mathrm{C}$ NMR.
The third compound $\mathbf{8}$ isolated from the second strain DC239, also isolated from the third strain P. viticola (Sacc.) Sacc. DC180, had a molecular formula of $\mathrm{C}_{18} \mathrm{H}_{26} \mathrm{O}_{5}$, as deduced from ${ }^{1} \mathrm{H},{ }^{13} \mathrm{C}$, and DEPT NMR spectroscopic data and HRESI MS (+) $345.1674[\mathrm{M}+\mathrm{Na}]^{+}$. The 1D and 2D NMR spectra in comparison with the literature led to the identification of compound $\mathbf{8}$ as cytosporone B, previously isolated from Cytospora sp. and Diaporthe sp. ${ }^{20}$

Biological activities for phomopsolide B (1) were previously reported for its antiboring/antifeeding activity against the elm bark beetle Scolytus sp. ${ }^{16}$ and its good antibacterial activity against Staphylococcus. aureus. ${ }^{21}$ Cytosporone B (8) was reported to have broad antifungal activities against Aspergillus niger, Trichoderma sp., Fusarium sp., and Candida albicans ${ }^{22}$ and antibacterial activity against the methicillin-resistant $S$. aureus (MRSA ) bacterial strain; ${ }^{23}$ however, there were no biological activities reported for sydowinin A and sydowinol.

Phytotoxic activity on grapevine leaves of cv. Chasselas was examined for all isolated compounds at the concentrations of 100,250 , and $500 \mu \mathrm{g} / \mathrm{mL}$. Eutypine, the major phytotoxin isolated from E. lata, ${ }^{24}$ was used as positive control at $500 \mu \mathrm{g} /$ $\mathrm{mL}$. Leaf necrosis was assessed $24 \mathrm{~h}$ after inoculation, and the values obtained are the mean of three replicates. Necrosis started to appears after $6 \mathrm{~h}$ at $500 \mu \mathrm{g} / \mathrm{mL}$ for cytosporone B (8) and eutypine. After 12 hours, eutypine, cytosporone B (8), and phomopsolide B (1) induced full necrosis on the leaf discs, whereas sydowinin A (6) and sydowinol (7) showed necrosis only on the leaf edges and phomopsolidones A-D did not induce leaf necrosis. The necrosis induced by phomopsolide $B$ (1) was a bleaching type in opposition to the brownish ones usually observed, whereas cytosporone B induced a brown necrosis and the green part of the leaf became darker. Phytotoxicity against grapevine callus tissue was performed only with the major compound phomopsolide B (1) that induced $100 \%$ inhibition of callus growth at $60 \mu \mathrm{g} / \mathrm{mL}$.

The antibacterial activity of compounds 1-3 was measured by the bioautography method on thin-layer chromatography against Bacillus subtilis and Escherichia coli. All three compounds showed minimal inhibitory concentration (MIC) at $0.1 \mathrm{ng}$ against B. subtilis but did not show activity at $200 \mathrm{ng}$ on E. coli.

Compounds 1-3) were subjected to a larvicidal assay on larvae of the grapevine moth L. botrana. The trial was carried out at 1 and $10 \mathrm{ppm}(\mathrm{mg} / \mathrm{kg})$. The larvicidal activity of the product was calculated in relation to the corresponding control experiment for both the larval surviving rate at 14 days and also for the whole duration of the trial up to moth emergence. For the larvae reared with the contaminated diet, no significant difference in the survival rate was observed. The larval survival rates with $10 \mathrm{ppm}$ at adult emergence reached $91.7 \%$ in the control, $65.0 \%$ with phomopsolide B (1), $90.0 \%$ with phomopsolidone A (2), and $68.3 \%$ with phomopsolidone B (3). The development delay at $10 \mathrm{ppm}$ was more significant. The mean development time for the larvae for the control was 28 days, for phomopsolide B (1) was 31.41 days, for phomopsolidone A (2) was 30.48 days, and for phomopsolidone B (3) was 34.41 days.

Phomopsolidones A and B (2 and 3) with the furanone moiety displayed weaker phytotoxic and antibacterial activities than phomopsolide B (1) with the pyranone moiety; these results are in accordance with the herbicidal activity reported for phomalactone A (pyranone) and its furanone cometabolites isolated from N. sacchari. ${ }^{24}$ 
Table 2. Strain Number, Species, Metabolites, and Cultivar Relationships: A Qualitative Analysis of Ethyl Acetate Extracts in HPLC-DAD-ESI MS as Reported in the Material and Methods Section ${ }^{a}$

\begin{tabular}{|c|c|c|c|c|c|c|c|}
\hline strain & species & isolated from & 1 & 2 & 6 & 7 & 8 \\
\hline $\mathrm{DC} 275^{b}$ & Phomopsis sp. & Merlot As & $\mathrm{X}$ & $\mathrm{X}$ & nd & nd & nd \\
\hline DC110 & Phomopsi sp. & Merlot As & $\mathrm{X}$ & $\mathrm{X}$ & nd & nd & nd \\
\hline DC283 & Phomopsis sp. & Merlot As & $\mathrm{X}$ & $\mathrm{X}$ & nd & nd & nd \\
\hline DC279 & Phomopsis sp. & Cabernet franc $S$ & $\mathrm{X}$ & $\mathrm{X}$ & nd & nd & $\mathrm{X}$ \\
\hline DC282 & Phomopsis sp. & Cabernet franc $S$ & $\mathrm{X}$ & $\mathrm{X}$ & nd & nd & $\mathrm{X}$ \\
\hline $\mathrm{DC} 281^{b}$ & P. viticola v. complex & Cabernet franc $S$ & nd & nd & nd & $\mathrm{X}$ & $\mathrm{X}$ \\
\hline $\mathrm{DC} 239^{b}$ & P. viticola v. complex & Cabernet sauvignon As & nd & nd & $\mathrm{X}$ & $\mathrm{X}$ & $\mathrm{X}$ \\
\hline $\mathrm{DC} 180^{b}$ & P. viticola Sacc. & Cabernet sauvignon As & nd & nd & nd & nd & $\mathrm{X}$ \\
\hline DC301 & Phomopsisp. & Cabernet sauvignon $S$ & $\mathrm{X}$ & $\mathrm{X}$ & nd & nd & $\mathrm{X}$ \\
\hline
\end{tabular}

Four out of the nine strains studied were identified by the Belgian Coordinated Collections of Microorganisms (BCCM) of the Catholic University of Louvain-la-Neuve. Strain DC180 was identified as the typical type of strain found on Vitis, $P$. viticola (Sacc.) Sacc. Strains DC239 and DC281) were described as being very similar, with the dimensions of $\alpha$ conidia slightly bigger than those described for the typical viticola strain. The molecular biological analysis and sequencing of the ITS and $28 \mathrm{~S}$ zones made it possible to note that the two samples have a succession of bases similar to that described by Mostert et al. ${ }^{1}$ called Phomopsis sp. 2 and taken up in the " $P$. viticola complex". Strain DC275 showed smaller $\alpha$-conidia and shorter $\beta$-conidia than those described for the viticola species, but a molecular biological study did not give results allowing further identification of the strain. Thus, the strain could only be identified as being a species belonging to the Phomopsis sp.

In order to examine the compounds produced as a function of strain species, the original LC-DAD-MS data of the nine strains were reinvestigated in the light of the identified metabolites (Table 2). The strains could be divided into three groups. The first group included the strain producing phomopsolide, phomopsolidones, and cytosporone B (strains DC110, DC275, DC283, DC279, DC282, and DC301) and correlate with Phomopsis sp. The second group included a strain producing cytosporone $\mathrm{B}(\mathbf{8})$ alone corresponding to $P$. viticola (Sacc.) Sacc (DC180), and finally, the third group producing cytosporone B (8) together with sydowinin A (6) and sydowinol (7) corresponded to P. viticola v. complex (strains DC239 and DC281). Three out of the six strains producing the phytotoxic phomopsolide B (1) were isolated from asymptomatic cv. Merlot (a less susceptible cultivar). From plants showing esca symptoms, ${ }^{12}$ two strains were isolated from Cabernet franc and one from Cabernet sauvignon (both sensitive cultivars); these strains produce compounds $\mathbf{1}$ and $\mathbf{2}$ together with cytosporone B (8). Strains producing cytosporone B (8) and xanthones 6 and 7 were isolated from symptomatic Cabernet franc and asymptomatic cv. Cabernet sauvignon. These results indicate that Phomopsis sp. of sensitive cultivars in plants showing esca symptoms produce the phytotoxic compounds phomopsolide B (1) and cytosporone $\mathrm{B}(8)$ raising the question of cultivar-driven strain selection and the stimulation of phytotoxins biosynthesis in grapevine plants. Phomopsolide B (1) has been reported from several species of Phomopsis from several host plants such as elm willow, quercus, platanus, heliconia, myrica, and liriodendron, ${ }^{7}$ indicating that the biosynthesis of this secondary metabolite does not seem to be correlated with the host plant from which the Phomopsis isolate was obtained. It is likewise for cytosporone B (8) reported from Phomopsis sp. isolated from different host plants such as cacao, coffee, and mango. ${ }^{25,26}$

This study revealed that the Phomopsis isolates, associated with grapevine showing esca decline, show high variability with regard to secondary metabolites production. The role played by the fungi is not clear, but they may be weak pathogens, saprophytes, or endophytes. ${ }^{5}$ The complexity of signaling between microorganisms and plants and between microorganisms themselves in grapevine trunk disease is still poorly understood. Characterization of metabolites biosynthesized by several fungi infecting grapevine wood is crucial not only for the phytotoxic properties but also is essential to better understand the conditions under which the fungi start producing the toxins and modify their lifestyle from endophytic to saprotrophic.

\section{ASSOCIATED CONTENT}

\section{S Supporting Information}

HRESI MS spectra of compounds 1-5, 7 and 8; ESI MS spectrum of 6; IR, ${ }^{1} \mathrm{H} \mathrm{NMR},{ }^{13} \mathrm{C} \mathrm{NMR}$, COSY, HSQC, and HMBC spectra of compounds 2 and 3. This material is available free of charge via the Internet at http://pubs.acs.org.

\section{AUTHOR INFORMATION}

\section{Corresponding Author}

*Phone: +41 2630088 05; e-mail: eliane.abou-mansour@unifr. ch.

\section{Present Addresses}

${ }^{\perp}$ Nicolas Mottier: Philip Morris Products SA, Quai Jeanrenaud 5, 2000 Neuchâtel, Switzerland.

\#Danilo Christen: Agroscope, Centre de recherche Conthey, Route des vergers 18, CH-1964 Conthey, Switzerland.

\section{Funding}

We thank Swiss National Science Foundation for their financial support (project no. 20-67972-02) and the National Centre of Competence in Research (NCCR) Plant Survival.

\section{Notes}

The authors declare no competing financial interest.

\section{ACKNOWLEDGMENTS}

We thank S. Unternaehrer for the biological tests on callus tissue. We thank Dr. P. Larignon (Institut Français de la Vigne et $\mathrm{du}$ Vin) for leaves and trunk necrosis photographs of the graphic, and Dr. Antony Buchala for English revision.

\section{REFERENCES}

(1) Mostert, L.; Crous, P. W.; Kang, J.-C. Species of Phomopsis and a Libertella sp. occurring on grapevines with specific reference to South 
Africa: Morphological, cultural, molecular and pathological characterization. Mycologia 2001, 93, 146-167.

(2) Pearson, R. C.; Goheen, R. C. Compendium of Grape Diseases; American Phytpathological Society Press: St. Paul, MN, 1994; pp 1718.

(3) Fisher, M.; Kassemeyer, H.-H. Fungi associated with Esca disease of grapevine in Germany. Vitis 2003, 42, 109-116.

(4) Urbez-Torres, J. R.; Leavitt, G. M.; Voegel, T. M.; Gubler, W. D. Identification and distribution of Botryosphaeria spp. associated with grapevine cankers in California. Plant Dis. 2006, 90, 1490-1503.

(5) Hofstetter, V.; Buyck, B.; Croll, D.; Viret, O.; Couloux, A.; Gindro, $\mathrm{K}$. What if esca disease of grapevine were not a fungal disease? Fungal Diversity 2012, 54, 51-67.

(6) Phillips, A. J. L. The relationship between Diaporthe perjuncta and Phomopsis viticola on grapevines. Mycologia 1999, 91, 1001-1007.

(7) Udayanga, D.; Liu, X.; McKenzie, E. H. C.; Chukeatirote, E.; Bahkali, A. H. A.; Hyde, K. D. The genus Phomopsis: Biology, applications, species concepts and names of common phytopathogens. Fungal Diversity 2011, 50, 189-225.

(8) Andolfi, A.; Mugnai, L.; Luque, J.; Surico, G.; Cimmino, A.; Evidente, E. Phytotoxins produced by fungi associated with grapevine trunk diseases. Toxins 2011, 3, 1569-1605.

(9) Tabacchi, R.; Fkyerat, A.; Poliart, C.; Dubin, G.-M. Phytotoxins from fungi of esca of grapevine. Phytopathol. Mediterr. 2000, 39, 156161.

(10) Djoukeng, J. D.; Polli, S.; Larignon, P.; Abou-Mansour, E. Identification of phytotoxins from Botryosphaeria obtusa, a pathogen of black dead arm disease of grapevine. Eur. J. Plant Pathol. 2009, 124, 303-308.

(11) Abou-Mansour, E.; Couché, E.; Tabacchi, R. Do fungal naphthalenones have a role in the development of esca symptoms? Phytopathol. Mediterr. 2004, 43, 75-82.

(12) Christen, D.; Schönmanna, S.; Jermini, M.; Strasser, R. J.; Défago, G. Characterization and early detection of grapevine (Vitis vinifera) stress responses to esca disease by in situ chlorophyll fluorescence and comparison with drought stress. Environ. Exp. Bot. 2007, 60, 504-514.

(13) Hadacek, F.; Greger, H. Testing of antifungal natural products: Methodologies, comparability of results and assay choice. Phytochem. Anal. 2000, 11, 137-147.

(14) Charmillot, P. J.; Pasquier, D.; Verneau, S. Efficacité larvicide de différents insecticides incorporés au milieu artificiel d'élevage sur les vers de la grappe 1 . Tests sur eudémis Lobesia botrana. Rev. Suisse Vitic., Arboric., Hortic. 2004, 36, 141-145.

(15) Grove, J. F. Metabolic products of Phomopsis oblonga. Part 2.sup.1. Phomopsolide A and B, tiglic esters of two 6-substituted 5, 6dihydro-5-hydroxypyran-2-ones. J. Chem. Soc., Perkin Trans I 1985, 4, 865-869.

(16) Claydon, N.; Grove, J. F.; Pople, M. Elm bark beetle boring and feeding deterrents from Phomopsis oblonga. Phytochemistry 1985, 24, 937-943.

(17) Horn, W. S.; Simmonds, M. S. J.; Schwartz, R. E.; Blaney, W. M. Variation in the production of phomodiol and phomopsolide B by Phomopsis. spp. Mycologia 1996, 88, 588-595.

(18) Fukushima, T.; Tanaka, M.; Gohbara, M.; Fujimori, T. Phytotoxicity of three lactones from Nigrospora sacchari. Phytochemistry 1998, 48, 625-630.

(19) Hamasaki, T.; Sato, Y.; Hatsuda, Y. Structure of sydowinin A, sydowinin B, and sydowinol, metabolites from Aspergillus sydowi. Agric. Biol. Chem. 1975, 39, 2341-5.

(20) Brady, S. F.; Wagenaar, M. M.; Singh, M. P.; Janso, J. E.; Clardy, J. The cytosporones, new octaketide antibiotics isolated from an endophytic fungus. Org. Lett. 2000, 2, 4043-4046.

(21) Stierle, D. B.; Stierle, A. A.; Ganser, B. New phomopsolides from a Penicillium sp. J. Nat. Prod. 1997, 60, 1207-1209.

(22) Huang, Z.; Cai, X.; Shao, C.; She, Z.; Xia, X.; Chen, Y.; Yang, J.; Zhou, S.; Lin, Y. Chemistry and weak antimicrobial activities of phomopsins produced by mangrove endophytic fungus Phomopsis sp. ZSU-H76. Phytochemistry 2008, 69, 1604-1608.
(23) Beau, J.; Mahid, N.; Burda, W.; Harrington, L.; Shaw, L.; Mutka, T.; Kyle, D. E.; Barisic, B.; Van Olphen, A.; Baker, B. Epigenetic tailoring for the production of anti-infective cytosporones from the marine fungus Leucostoma persoonii. Mar. Drugs 2012, 10, 762-774.

(24) Renaud, J.-M.; Tsoupras, G.; Tabacchi, R. Biologically active natural acetylenic compounds from Eutypa lata (Pers.:Fr.)Tul. Helv. Chim. Acta 1989, 72, 929-932.

(25) Toshiro, F.; Masayasu, T.; Masatoshi, G.; Takane, F. Phytotoxicity of three lactones from Nigrospora sacchari. Phytochemistry 1998, 48, 625-630.

(26) Abreu, L. M.; Costa, S. S.; Penning, L. H.; Takahashi, J. A.; Larsen, T. O.; Andersen, B. Chemical and molecular characterization of Phomopsis and Cytospora-like endophytes from different host plants in Brazil. Fungal Biol. 2012, 116, 249-260. 